\title{
Ammonium Dissociation for Swine and Dairy Cattle Manures
}

\author{
Min Liu ${ }^{1}$, David Giard ${ }^{2}$, Suzelle Barrington ${ }^{2,3 *}$ \\ ${ }^{1}$ China Institute of Nuclear Information and Economics, Beijing, China; ${ }^{2}$ Department of Building, Civil and Environmental Engi- \\ neering, Concordia University, Montreal, Canada; ${ }^{3}$ Consumaj Inc., Quebec, Canada. \\ Email: ${ }^{*}$ suzellebarrington@sympatico.ca
}

Received March $8^{\text {th }}, 2013$; revised April 9 $9^{\text {th }}, 2013$; accepted May $7^{\text {th }}, 2013$

Copyright (C) 2013 Min Liu et al. This is an open access article distributed under the Creative Commons Attribution License, which permits unrestricted use, distribution, and reproduction in any medium, provided the original work is properly cited.

\begin{abstract}
The dissociation of ammonium $\left(\mathrm{NH}_{4}^{+}\right)$into ammonia $\left(\mathrm{NH}_{3}\right)$ in wastewaters is a key factor governing atmospheric nitrogen volatilization. Relatively rich in total ammoniacal nitrogen (TAN or $\mathrm{NH}_{4}^{+}$plus $\mathrm{NH}_{3}$ ), livestock manures are most susceptible to $\mathrm{NH}_{3}$ volatilization, although indirect measurements report 5 times less $\mathrm{NH}_{4}^{+}$dissociation as compared to theoretical values. The objective of this study was therefore to directly measure $\mathrm{NH}_{4}^{+}$dissociation of two standard $\mathrm{NH}_{4} \mathrm{Cl}$ solutions (1750 and $3500 \mathrm{mg}$ TAN/L), and of swine and dairy cattle manures at various dilutions and temperatures using a ammonia selective electrode (hydrogen and silver-silver chloride electrode couple) at various $\mathrm{pH}$ and temperatures. All solutions demonstrated $\mathrm{NH}_{4}^{+}$dissociation varying from theory, especially because of dissolved compounds such as atmospheric $\mathrm{CO}_{2}$. At a neutral $\mathrm{pH}$, ratios of theoretical to measured $\left[\mathrm{NH}_{3}-\mathrm{N}\right]$ ranged from 1.5 to 3.5 , with higher ratios corresponding to higher TAN levels. At a $\mathrm{pH}$ below $6, \mathrm{NH}_{3}$ volatilization was enhanced by the shift of $\mathrm{HCO}_{3}^{-}$to $\mathrm{H}_{2} \mathrm{CO}_{3}$ and $\mathrm{CO}_{2}$. With previous research projects reporting 5 times less $\mathrm{NH}_{3}$ volatilization as compared to theory, the present indicates that dissociation activity account for half of this drop with gas diffusion accounting for the other half.
\end{abstract}

Keywords: Ammonium Dissociation; Manure; pH; Temperature

\section{Introduction}

Worldwide, food production generates $70 \%$ of the global ammonia $\left(\mathrm{NH}_{3}\right)$ emissions, representing 55 million tons/ yr [1] and being concentrated especially in Europe, the Indian subcontinent, China and the US [2-4]. Within this $70 \%$, fertilizers and livestock manures contribute 10 - 12 and 16 - 27 million tons/yr of $\mathrm{NH}_{3}-\mathrm{N}$ volatilization, respectively, where the share of livestock shelters including manure storage and manure land spreading is 30 to $55 \%$ and $15 \%$ to $40 \%$, respectively [5].

Nitrogen deposition as a result of $\mathrm{NH}_{3}-\mathrm{N}$ atmospheric loading leads to several well acknowledged environmental issues: increased risks of water eutrophication [6,7] and acidification [8]; $\mathrm{N}$ accumulations changing plant species for soils [9,10], and benthic and pelagic

${ }^{*}$ Corresponding author. organisms such as corals and algae for waters [11]; increased organic soil subsidence [12]; increased crop sensitivity to secondary stresses such as pathogens, frost and drought [13]; increased $\mathrm{CO}_{2}$ emissions from forest soils [14], and; damages to tomatoes, cucumbers, conifers and fruit crops [15].

Models simulating $\mathrm{NH}_{3}$ volatilization from wastewaters rich in $\mathrm{NH}_{4}^{+}$such as livestock manure, are based on a dissociation constant $\mathrm{p} K_{\mathrm{a}}$. Nevertheless, available $\mathrm{p} K_{\mathrm{a}}$ coefficients pertain to pure solutions rather than natural solutions containing gases dissolved from the atmosphere and minerals in trace quantities. Hashimoto and Ludington [16] estimated the $\mathrm{p} K_{\mathrm{a}}$ coefficient of poultry manure slurries by measuring $\mathrm{NH}_{3}$ volatilization in reaction vessels equipped with a mixing system and assuming a value for Henry's constant equivalent to that of water. They recommended a manure $\mathrm{p} K_{\mathrm{a}}$ coefficient 5 times lower than that computed theoretically for pure water solutions. 
Similarly for dairy manure, Chaoui et al. [17] observed a $\mathrm{p} K_{\mathrm{a}}$ coefficients $80 \%$ smaller than those predicted theoretically by measuring the rate of $\mathrm{NH}_{3}$ volatilization from non stirred jars and once more, assuming a value for Henry's constant equivalent to that of water. Such low $\mathrm{NH}_{4}^{+}$dissociation levels were used by Zhang et al. [18] to produce a model predicting $\mathrm{NH}_{3}$ losses from manures and by Masse et al. [19] estimating the efficiency of a membrane separation technology.

The assumption that Henry's constant in manures is the same as that of water may introduce an error in estimating $\mathrm{p} K_{\mathrm{a}}$ since the solids content of manures increases their viscous properties and accordingly, decreases their rate of gas diffusion [20]. For anaerobic digesters, Hafner and Bisogni [21] demonstrated that the presence in particular of inorganic carbon could modify $\mathrm{p} K_{\mathrm{a}}$ by $20 \%$. To obtain $\mathrm{p} K_{\mathrm{a}}$ values without estimating Henry's constant, $\mathrm{NH}_{3}$ in solutions must de directly measured. Since the silver-silver chloride electrode, namely the $\mathrm{NH}_{3}$ selective electrode, is recognized as a reliable instrument to measure $\mathrm{NH}_{3}$ in solutions $[22,23]$ being sold by several electrode manufacturers, this method is proposed to directly measure $\mathrm{NH}_{3}$ concentrations and compute measured $\mathrm{p} K_{\mathrm{a}}$ coefficients [22,23].

The objective of the present paper was to directly measure the concentration of $\mathrm{NH}_{3}$ resulting from $\mathrm{NH}_{4}^{+}$ dissociation at various temperatures and $\mathrm{pH}$, for two $\mathrm{NH}_{4} \mathrm{Cl}$ solutions and for fresh swine and dairy cattle manures at different dilution levels. Concentrations of $\mathrm{NH}_{3}\left(\left[\mathrm{NH}_{3}-\mathrm{N}\right]\right)$ were directly measured using a $\mathrm{NH}_{3}$ selective electrode connected to a $\mathrm{pH}$ meter (Orion, Boston, USA) and converted into a dissociation coefficient $\mathrm{p} K_{\mathrm{a}}$. The two $\mathrm{NH}_{4} \mathrm{Cl}$ solutions had a Total Available Nitrogen (TAN or $\mathrm{NH}_{4}^{+}-\mathrm{N}$ plus $\mathrm{NH}_{3}-\mathrm{N}$ ) of 1750 and $3500 \mathrm{mg} / \mathrm{L}$, and the swine and dairy cattle manures were diluted to various levels with distilled water to offer a TAN in the range of 400 to $3800 \mathrm{mg} / \mathrm{L}$.

\section{Chemistry of Ammonium Dissociation}

Because of the polar nature of water molecules, $\mathrm{H}^{+}$ions are constantly being exchanged and a self ionization coefficient, $\mathrm{p} K_{\mathrm{w}}$, of more or less 14 is exhibited:

$$
\mathrm{p} K_{\mathrm{w}}=14=-\log _{10}\left(10^{-14}\right)=\left[\mathrm{H}^{+}\right] \times\left[\mathrm{OH}^{-}\right]
$$

Pure water exhibits equal concentrations of $\mathrm{H}^{+}$and $\mathrm{OH}^{-}$, $\left[\mathrm{H}^{+}\right]$and $\left[\mathrm{OH}^{-}\right]$, or a $\mathrm{pH}\left(-\mathrm{Log}_{10}\left[\mathrm{H}^{+}\right]\right)$of 7 . Ionic elements or compounds dissolved in water take part in the exchange of $\mathrm{H}^{+}$, shifting the $\mathrm{pH}$ under or above 7 , whether an acid or a base generating $\mathrm{H}^{+}$or $\mathrm{OH}^{-}$, respectively.

The ion $\mathrm{NH}_{4}^{+}$is a weak acid dissociating as follows in water:

$$
\mathrm{NH}_{4}^{+} \leftrightarrow \mathrm{NH}_{3}+\mathrm{H}^{+}
$$

The level of $\mathrm{NH}_{4}^{+}$dissociation into $\mathrm{NH}_{3}$ depends on the availability of $\mathrm{H}^{+}$in solution, where a deficit (alkaline conditions) shifts Equation (2) to the right, thus releasing $\mathrm{H}^{+}$from $\mathrm{NH}_{4}^{+}$and producing $\mathrm{NH}_{3}$. The extent of this dissociation process is expressed by the dissociation coefficient $K_{\mathrm{a}}$, defined as follows:

$$
K_{\mathrm{a}}=\left[\mathrm{H}^{+}\right] \times\left[\mathrm{NH}_{3}\right] /\left[\mathrm{NH}_{4}^{+}\right]
$$

Since $K_{\mathrm{a}}$ coefficients are generally very small, such as that of water at $10^{-7}$, the general practice is to express dissociation coefficients as $\mathrm{p} K_{\mathrm{a}}$ where:

$$
\mathrm{p} K_{\mathrm{a}}=-\log _{10}\left(K_{\mathrm{a}}\right)
$$

This principle of dissociation applies to all acids $\left(\mathrm{p} K_{\mathrm{a}}\right)$ and bases $\left(\mathrm{p} K_{\mathrm{b}}\right)$ dissolved in water. The higher the value of $K_{\mathrm{a}}$, or the lower the value of $\mathrm{p} K_{\mathrm{a}}$, the more active is the acid, and the greater is the extent of dissociation exchanging $\mathrm{H}^{+}$ions.

For pure $\mathrm{NH}_{4}^{+}$solutions in water, the dissociation coefficient, $\mathrm{p} K_{\mathrm{a}}$, was initially determine in the 1940's by measuring the electromotive forces created in a cell between a hydrogen and silver-silver chloride electrode couple (Bates and Pinching 1949). Such cell better known as a $\mathrm{NH}_{3}$ sensitive electrode can produce an error of + /$5 \%$ [24] as a result of variations in the solution solubility of silver chloride and losses of $\mathrm{NH}_{3}$ during the reading process [23]. The ratio of $\mathrm{NH}_{3}$ to TAN, $f$, can be defined in terms of $\mathrm{pH}[25]$ based on:

$$
\begin{aligned}
K_{\mathrm{a}} & =\left(\left[\mathrm{H}^{+}\right] \times\left[\mathrm{NH}_{3}\right]\right) / \mathrm{NH}_{4}^{+} \\
& =\left(\left[\mathrm{H}^{+}\right] \times\left[\mathrm{NH}_{3}\right]\right) /\left(\mathrm{TAN}-\mathrm{NH}_{3}\right)
\end{aligned}
$$

The solution to this equation gives (Loehr, 1984):

$$
f=\left(\left[\mathrm{NH}_{3}\right]\right) / \mathrm{TAN}=1 /\left(1+10^{\left(\mathrm{pK}_{\mathrm{a}}-\mathrm{pH}\right)}\right)
$$

To compute $\mathrm{p} K_{\mathrm{a}}$, the temperature effect can be included as [26]:

$$
\mathrm{p} K_{\mathrm{a}}=0.09018+(2729.92 / T)
$$

where $T$ is in ${ }^{\circ} \mathrm{K}$.

Water solutions are rarely pure and $\mathrm{p} K_{\mathrm{a}}$ reported for pure TAN solutions cannot be applied. In natural solutions, the extent of the dissociation process depends not only on the solution $\mathrm{pH}$ but also the presence of other acids or bases readily exchanging $\mathrm{H}^{+}$without a noticeable change in $\mathrm{pH}$ [27]. An important acid affecting $\left[\mathrm{H}^{+}\right]$in water solution is carbonic acid $\left(\mathrm{H}_{2} \mathrm{CO}_{3}\right)$ generated from $\mathrm{CO}_{2}$ dissolved from the atmosphere or produced from microbial activity degrading organic matter. Carbonic acid releases $\mathrm{H}^{+}$as the $\mathrm{pH}$ increases or $\left[\mathrm{H}^{+}\right]$decreases, with the maximum $\left[\mathrm{HCO}_{3}^{-}\right]$and $\left[\mathrm{CO}_{3}^{2-}\right]$ occurring at a $\mathrm{pH}$ of 6.5 and 10.5, respectively [28,29]:

$$
\mathrm{H}_{2} \mathrm{CO}_{3} \leftrightarrow \mathrm{HCO}_{3}^{-}+\mathrm{H}^{+} \leftrightarrow \mathrm{CO}_{3}^{2-}+\mathrm{H}^{+}
$$


By releasing $\mathrm{H}^{+}, \mathrm{HCO}_{3}^{-}$creates a buffering effect and increases the amount of available $\mathrm{H}^{+}$, thus potentially decreasing the dissociation of $\mathrm{NH}_{4}^{+}$into $\mathrm{NH}_{3}$. Furthermore $\mathrm{HCO}_{3}^{-}$is the preferred ionic form as compared to $\mathrm{CO}_{3}^{2-}$, with a lower pKa coefficient (Table 1).

Besides dissolved atmospheric and microbial $\mathrm{CO}_{2}$, manures offer a wide range of compounds interfering with $\mathrm{H}^{+}$exchanges, such as phosphates, with maximum concentrations of $\mathrm{H}_{2} \mathrm{PO}_{4}^{-}$and $\mathrm{HPO}_{4}^{2-}$ occurring at a $\mathrm{pH}$ of 5 and 9.5, and with $\mathrm{p} K_{\mathrm{a}}$ of 2.13, 7.20 and 12.37 for $\left[\mathrm{H}_{2} \mathrm{PO}_{4}^{-}\right],\left[\mathrm{HPO}_{4}^{2-}\right]$ and $\left[\mathrm{PO}_{4}^{3-}\right]$ respectively (Table 1):

$$
\begin{aligned}
& \mathrm{H}_{3} \mathrm{PO}_{4} \leftrightarrow \mathrm{H}_{2} \mathrm{PO}_{4}^{-}+\mathrm{H}^{+} \\
& \leftrightarrow \mathrm{HPO}_{4}^{2-}+\mathrm{H}^{+} \leftrightarrow \mathrm{PO}_{4}^{3-}+\mathrm{H}^{+}
\end{aligned}
$$

As compared to $\mathrm{NH}_{4}^{+}$, both $\mathrm{H}_{3} \mathrm{PO}_{4}$ and $\mathrm{H}_{2} \mathrm{CO}_{3}$ have smaller $\mathrm{p} K_{\mathrm{a}}$ coefficients, with a greater potential of governing the availability and exchange of $\mathrm{H}^{+}$.

In conclusion, the dissociation coefficients expressed by $\mathrm{pKa}$ developed for pure solutions of specific acids, including $\mathrm{NH}_{4}^{+}$, cannot be directly applied to natural solutions because of the presence and interaction of other more active species. Compared to water solutions with a limited amount of dissolved ions and solids, wastewaters such as manure can present a more complex reaction affecting $\mathrm{NH}_{4}^{+}$dissociation, thus the need to conduct direct measurements.

\section{Materials and Methods}

\subsection{Experimental Solutions}

Fresh dairy cattle and swine manures were collected from the Dairy Cattle and Swine Complexes of the Macdonald Campus Research Farm of McGill University, located at the western tip of the island of Montreal, Canada. The samples were transported to the laboratory and refrigerated at $5^{\circ} \mathrm{C}$ to $6^{\circ} \mathrm{C}$ until used. Each sample was characterized in triplicate for total solids (TS), total volatile solids (TVS), pH, total Kjeldhal nitrogen (TKN),

Table 1. Values of $\mathrm{p} K_{\mathrm{a}}$ and $\mathrm{p} K_{\mathrm{b}}$ for some weak acids gener-

\begin{tabular}{|c|c|c|c|}
\hline Acid & $\mathrm{p} K_{\mathrm{a}}$ & Base & $\mathrm{p} K_{\mathrm{b}}$ \\
\hline Phosphoric acid $\mathrm{H}_{3} \mathrm{PO}_{4}$ & 2.125 & $\mathrm{H}_{2} \mathrm{PO}_{4}^{-}$ & 11.89 \\
\hline Acetic acid $\mathrm{HC}_{2} \mathrm{H}_{3} \mathrm{O}_{2}$ & 4.74 & $\mathrm{C}_{2} \mathrm{H}_{3} \mathrm{O}_{2}^{-}$ & 9.25 \\
\hline Propionic acid $\mathrm{HC}_{3} \mathrm{H}_{5} \mathrm{O}_{2}$ & 4.85 & $\mathrm{C}_{3} \mathrm{H}_{5} \mathrm{O}_{2}^{-}$ & 9.15 \\
\hline Carbonic acid $\mathrm{H}_{2} \mathrm{CO}_{3}$ & 6.38 & $\mathrm{HCO}_{3}^{-}$ & 7.62 \\
\hline Ammonium $\mathrm{NH}_{4}^{+}$ & 9.25 & $\mathrm{NH}_{3}$ & 4.75 \\
\hline Hydrogen carbonate ion $\mathrm{HCO}_{3}^{-}$ & 10.32 & $\mathrm{CO}_{3}^{2-}$ & 3.67 \\
\hline
\end{tabular}
ally found in manures.

Note: higher $\mathrm{p} K_{\mathrm{a}}$ values represent an acid with a higher dissociation potential.
TAN, total phosphorous (TP) and total potassium (TK), according to standard methods (APHA, 2005). To conduct the $\mathrm{NH}_{3}$ trials, swine manure was tested whole and after being diluted with distilled water, while dairy cattle manure, harder to stir because of its fibrous solids, was only tested at a dilution ratio of 1:4. The $\mathrm{NH}_{4} \mathrm{Cl}$ salt used to prepare the standard solutions was purchased from Fisher Scientific (98\% purity).

\subsection{Methodology}

The $\mathrm{NH}_{3}$ sensitive electrode is a well recognized method for the measurement of TAN concentrations in solutions and manures. Generally, the $\mathrm{pH}$ is adjusted to 13 , to dissociate practically all $\mathrm{NH}_{4}^{+}$into $\mathrm{NH}_{3}$. Therefore, this project use an $\mathrm{NH}_{3}$ sensitive electrode as follows to directly measure $\left[\mathrm{NH}_{3}-\mathrm{N}\right]$ [24]: 1) the $\mathrm{pH}$ of a standard $\mathrm{NH}_{4} \mathrm{Cl}$ solution or manure sub-sample was increased to 13 using $5 \mathrm{M} \mathrm{NaOH}$ and its TAN (total $\mathrm{NH}_{3}$ and $\mathrm{NH}_{4}^{+}$) was measured; 2) another sub-sample of the same $\mathrm{NH}_{4} \mathrm{Cl}$ solution or manure sample was tested for $\mathrm{NH}_{3}-\mathrm{N}$ after gradually changing its $\mathrm{pH}$ no more than 4 times, with either HCL or $\mathrm{NaOH}$, while also measuring its temperature; 3 ) the process was repeated at various $\mathrm{pH}$ and temperatures. The measured $\mathrm{NH}_{3}$-N/TAN fraction $f$ was used to compute the measured $\mathrm{p} K_{\mathrm{a}}$ coefficient for a given $\mathrm{pH}$ and temperature as follows:

$$
\text { Measured } \mathrm{p} K_{\mathrm{a}}=\mathrm{pH}+\log _{10}(1 / f-1)
$$

The temperature of the solutions and manures was modified by storing in a closed flask in a refrigerator or leaving on a bench top for $24 \mathrm{~h}$ to obtain room temperature. The temperature of the solution or manure was measured using a standard mercury laboratory thermometer with an accuracy of $+/-0.5^{\circ} \mathrm{C}$. Solutions of $1 \mathrm{M}$ $\mathrm{HCl}$ and $5 \mathrm{M} \mathrm{NaOH}$ were used respectively to drop and increase the $\mathrm{pH}$.

The procedure described above was initially used to quantify $\left[\mathrm{NH}_{3}\right]$ in standard $\mathrm{NH}_{4} \mathrm{Cl}$ solutions of 3500 and $1750 \mathrm{mg}$ TAN/L, at a $\mathrm{pH}$ increased from 6 to 13 and a temperature ranging from $15^{\circ} \mathrm{C}$ to $25^{\circ} \mathrm{C}$. For each $\mathrm{pH}$ and temperature combination, the procedure was repeated 3 times.

The manure samples were tested at various $\mathrm{pH}$ using the same procedure. Swine manure with a $8.8 \%$ total solids (TS) was tested at a temperature and dilution ratio with distilled water of: $20^{\circ} \mathrm{C}-25^{\circ} \mathrm{C}$ at a dilution of $0(1$ part manure and 0 part distilled water); $8^{\circ} \mathrm{C}-15^{\circ} \mathrm{C}$ and $20^{\circ} \mathrm{C}-25^{\circ} \mathrm{C}$ at a dilution ratio of $1(1$ part manure and 1 part distilled water), and; $8^{\circ} \mathrm{C}-15^{\circ} \mathrm{C}$ and $20^{\circ} \mathrm{C}-25^{\circ} \mathrm{C}$ at a dilution ratio of 4 (1 part manure and 4 part distilled water). The procedure was repeated with $9.9 \%$ TS cattle manure at temperatures of $8^{\circ} \mathrm{C}$ to $25^{\circ} \mathrm{C}$, diluted with distilled water at a ratio of 4 ( 1 part manure and 4 part dis- 
tilled water). All measured $\mathrm{NH}_{3}$ concentrations, $\mathrm{p} K_{\mathrm{a}}$, coefficients and $f$ fraction were compared to those obtained theoretically using Equations 4b.

\subsection{Analytical Procedure}

Both the swine and dairy manure samples were analyzed using standard methods (APHA 2005) for total solids (TS), and total volatilize solids (TVS), $\mathrm{pH}$, total Kjeldhal nitrogen (TKN), total phosphorous (TP) and total potassium (TK). Total solids were determined by drying at $103^{\circ} \mathrm{C}$ for $24 \mathrm{~h}$ in an oven (Scientific John by Sheldon Manufacturing Inc., Cornelius, Oregon, USA). The TVS were determined by burning the dried samples for $4 \mathrm{~h}$ in a muffle furnace (Blue M Electric Company, Blue Island, Illinois, USA). The $\mathrm{pH}$ was determined using a $\mathrm{pH}$ probe attached to a pH/Ion meter (Orion Model 450, Boston, Massachusetts, USA).

The TAN value was measured by increasing the $\mathrm{pH}$ of the solution to 13 using $5 \mathrm{M} \mathrm{NaOH}$, and using an $\mathrm{NH}_{3}$ selective electrode (Orion 9512HBNWP ammonia sensitive electrode, Boston, USA) for quantification with an accuracy of $2 \%$ of the reading. Total Kjeldhal nitrogen (TKN) was determined after digesting the samples in 18 $\mathrm{M}$ sulfuric acid and 50\% hydrogen peroxide for $15 \mathrm{~min}-$ utes at $500^{\circ} \mathrm{C}$. The TKN of the digested samples was determined at a $\mathrm{pH}$ of 13 , using an $\mathrm{NH}_{3}$ selective electrode connected to a $\mathrm{pH}$ meter. The electrode was calibrated before hand using standard $\mathrm{NH}_{4} \mathrm{Cl}$ solutions. The $\mathrm{TP}$ and TK of the digested samples were quantified at a $\mathrm{pH}$ of 7, using a spectrophotometer (Hach, Model DR 5000, Loveland, Co., USA).

\subsection{Statistical Analysis}

Standard deviations were obtained using Excel (Microsoft Office 2007, Seattle, USA). The ANOVA was used to measure differences between treatments (solution type and temperature), where $\mathrm{pH}$ range was used as block.

\section{Results and Discussion}

\subsection{Characteristics of the Experimental Manures}

The characteristics of the experimental cattle and swine manures are described in Table 2. The two manures had similar TS with that of dairy cattle and swine offering 9.9 and $8.8 \%$, respectively. The TKN and TAN concentrations differed between the dairy and swine manure, with the dairy manure offering concentrations of 3720 and $2170 \mathrm{mg} / \mathrm{L}$, and the swine manure offering concentrations of 5500 and $3825 \mathrm{mg} / \mathrm{L}$, respectively. The $\mathrm{pH}$ of both manures was in the neutral range of 7.4 and 7.1 respectively. The total phosphorous and potassium content of the swine manure were higher than those of the dairy
Table 2. Characteristics of the experimental manures.

\begin{tabular}{ccc}
\hline Characteristic & Dairy cattle manure & Grower swine manure \\
\hline TS (\%) & $9.9(0.40)$ & $8.8(0.16)$ \\
TVS (\% of TS) & $80(0.2)$ & $83(0.6)$ \\
pH & $7.4(0.08)$ & $7.1(0.05)$ \\
TKN (mg/L) & $3720(720)$ & $5500(910)$ \\
TAN (mg/L) & $2170(195)$ & $3825(365)$ \\
TP (mg/L) & $700(105)$ & $2020(250)$ \\
TK (mg/L) & $2600(310)$ & $3700(720)$ \\
\hline
\end{tabular}

Note: the value in parenthesis is the standard deviation based on three samples.

cattle manure at 2020 and $3700 \mathrm{mg} / \mathrm{L}$, compared to 700 and $2600 \mathrm{mg} / \mathrm{L}$.

\subsection{Ammonium Dissociation for $\mathrm{NH}_{4} \mathrm{Cl}$ Water Solutions}

The $\mathrm{pH}$ of the $\mathrm{NH}_{4} \mathrm{Cl}$ solutions at various temperatures ranging from $15^{\circ} \mathrm{C}$ to $25^{\circ} \mathrm{C}$ is the first interesting observation. At $15^{\circ} \mathrm{C}$ and $25^{\circ} \mathrm{C}$ and in pure water, $\mathrm{NH}_{4}^{+}$exhibits a $\mathrm{p} K_{\mathrm{a}}$ of 9.55 and 9.24 computed from Equation 5. Accordingly, 0.25 and 0.125 molar $\mathrm{NH}_{4}^{+}$solutions (3500 and $1750 \mathrm{mg}$ TAN/L) should produce a $\mathrm{pH}$ of 4.9 and 5.1, respectively. For the solution at 0.25 molar $\mathrm{NH}_{4}^{+}-\mathrm{N}$ (3500 mg/L TAN), the observed $\mathrm{pH}$ ranged from 5.6 to 5.9 irrespective of the temperature ranging from $15^{\circ} \mathrm{C}$ to $20^{\circ} \mathrm{C}$. Another series of tests produced a pH of 5.9 to 6.0 at $25^{\circ} \mathrm{C}$ for the 0.125 and 0.25 molar $\mathrm{NH}_{4}^{+}-\mathrm{N}$ (1750 and $3500 \mathrm{mg} / \mathrm{L}$ TAN) solutions.

The discrimination between the measured and expected $\mathrm{pH}$ therefore resulted from the interference of other dissolved compounds or elements at the time of testing, besides the effect of $\mathrm{NH}_{4} \mathrm{Cl}$. Because the observed $\mathrm{pH}$ was higher than that expected theoretically, the dissolved compounds or elements were either absorbing the $\mathrm{H}^{+}$ions generated by the $\mathrm{NH}_{4}{ }^{+}$dissociating into $\mathrm{NH}_{3}$, or simply attenuating the extent of the dissociation process as a result of a higher $\mathrm{H}^{+}$availability. Since the $\mathrm{NH}_{4} \mathrm{Cl}$ solution was prepared in distilled water, dissolved atmospheric $\mathrm{CO}_{2}$ with a $\mathrm{p} K_{\mathrm{a}}$ of 6.35 is the most logical compound capable of producing such interference. Since the measurements were conducted in January and February, the ambient laboratory air likely contained $\mathrm{CO}_{2}$ levels of 800 to $1000 \mathrm{ppm}$, standard winter $\mathrm{CO}_{2}$ concentrations in public buildings. These concentrations enhanced the amount of dissolved $\mathrm{CO}_{2}$ and accordingly $\mathrm{H}_{2} \mathrm{CO}_{3}$. Accordingly, the initial solution $\mathrm{pH}$ indicated that $\mathrm{NH}_{4}^{+}$dissociation was influenced by other dissolved compounds primarily dissolved from the atmospheric, such as $\mathrm{CO}_{2}$ forming $\mathrm{HCO}_{2}^{-}$absorbing $\mathrm{H}^{+}$and 
buffering a change in $\mathrm{pH}$ with the addition of $\mathrm{NH}_{4} \mathrm{Cl}$.

The ratio of theoretical to measured $\left[\mathrm{NH}_{3}\right]$ is presented in Figure 1(a), for both $\mathrm{NH}_{4} \mathrm{Cl}$ solutions, as a function of $\mathrm{pH}$. The first observation is that, below a pH of 6.5, the $3500 \mathrm{mg} \mathrm{TAN} / \mathrm{L}$ at $15^{\circ} \mathrm{C}-20^{\circ} \mathrm{C}$ and $1750 \mathrm{mg} \mathrm{TAN} / \mathrm{L}$ at $25^{\circ} \mathrm{C}$ produced a ratio generally under 1.0 , except for the $3500 \mathrm{mg} \mathrm{TAN} / \mathrm{L}$ solution at $25^{\circ} \mathrm{C}$ which produced a ratio between 0.9 and 1.5. At a $\mathrm{pH}$ above 6.5, both the 3500 mg TAN/L produced a peak ratio of 2.3, as compared to the $1750 \mathrm{mg}$ TAN/L producing a peak ratio of 1.5 . At $25^{\circ} \mathrm{C}$, and compared to the $3500 \mathrm{mg} / \mathrm{L}$ solution, the 1750 $\mathrm{mg} / \mathrm{L}$ solutions produced a lower theoretical to measured $\left[\mathrm{NH}_{3}\right]$ ratio for a $\mathrm{pH}$ range of 7.7 to 8.7 (95\% probability).

The observed ratio of theoretical to measured $\left[\mathrm{NH}_{3}\right]$ in Figure 1(a) is explained by the buffering action of $\mathrm{H}_{2} \mathrm{CO}_{3}$. When adding a weak acid such as $\mathrm{NH}_{4}^{+}$to a solution of $\mathrm{HCO}_{3}^{-}$, the reaction illustrated by Equation 6 shifts to the left, thus producing $\mathrm{H}_{2} \mathrm{CO}_{3}$ absorbing $\mathrm{H}^{+}$, creating a $\mathrm{H}^{+}$deficit and increasing $\left[\mathrm{NH}_{3}\right]$. Furthermore, this left shift of reaction for Equation 6 releases $\mathrm{CO}_{2}$ to the atmosphere further increasing the deficit of $\mathrm{H}^{+}$. This

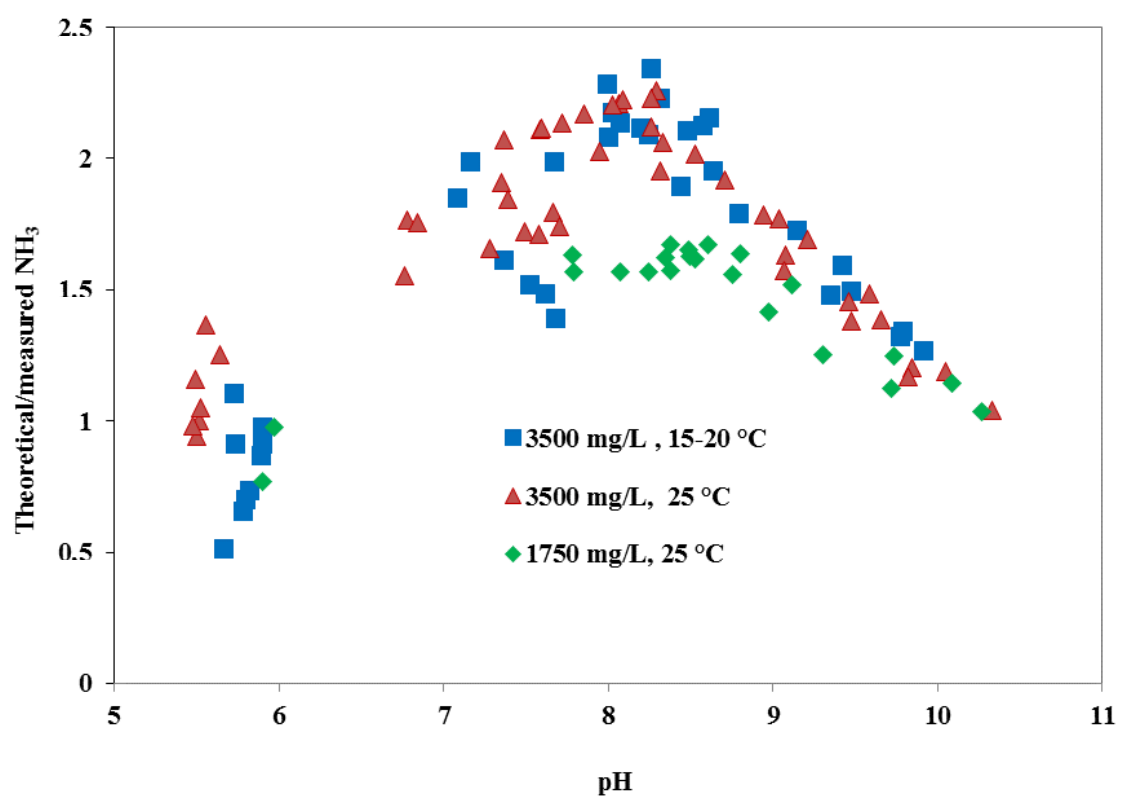

(a)

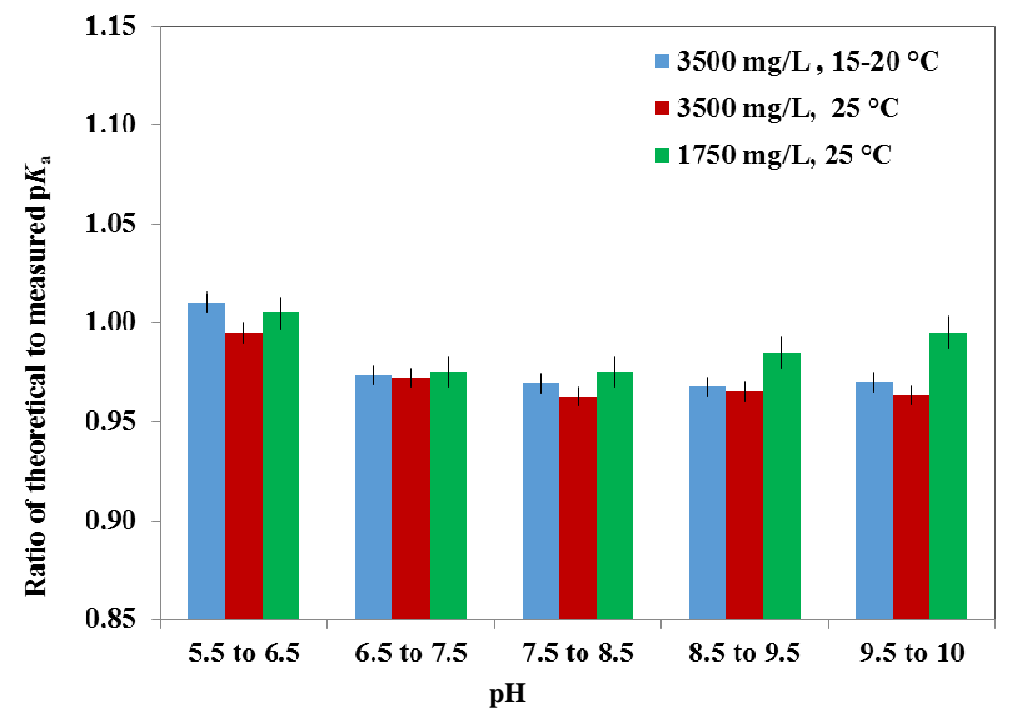

(b)

Figure 1. (a) Ratio of theoretical to measured $\mathrm{NH}_{3}$ concentrations as a function of $\mathrm{pH}$ for $\mathrm{NH}_{4} \mathrm{Cl}$ solutions of $3500 \mathrm{mg}$ TAN/L at $15^{\circ} \mathrm{C}-20^{\circ} \mathrm{C}$ and $25^{\circ} \mathrm{C}$ and $1750 \mathrm{mg}$ TAN/L at $25^{\circ} \mathrm{C}$. (b) Average ratio of the theoretical to measured pK as a function of $\mathrm{pH}$ ranges selected to highlight significant difference, for $\mathrm{NH}_{4} \mathrm{Cl}$ solutions of $3500 \mathrm{mg} \mathrm{TAN} / \mathrm{L}$ at $15^{\circ} \mathrm{C}-20^{\circ} \mathrm{C}$ and $25^{\circ} \mathrm{C}$ and $1750 \mathrm{mg}$ TAN/L at $25^{\circ} \mathrm{C}$. The error bar is based on the coefficient of variance. 
phenomenon is also observed in high salt solutions where $\mathrm{CO}_{2}$ solubility is reduced. Finally, this left shift of reaction for Equation 6 results in the absorption of $\mathrm{H}^{+}$ions, explaining the higher observed $\mathrm{pH}$ discussed above. For the $3500 \mathrm{mg} \mathrm{TAN} / \mathrm{L}$ solution at $25^{\circ} \mathrm{C}$ with a higher ratio of theoretical to measured $\left[\mathrm{NH}_{3}\right]$ as compared to the other treatments, the explanation is a higher $\mathrm{NH}_{4}^{+}$concentration versus a lower dissolved $\mathrm{CO}_{2}$ presence, thus shifting the $\mathrm{H}^{+}$balance. At $25^{\circ} \mathrm{C}, \mathrm{CO}_{2}$ is less soluble.

At a $\mathrm{pH}$ above 6, the $\left[\mathrm{OH}^{-}\right]$increases and the reverse reaction happens. The measured $\left[\mathrm{NH}_{3}\right]$ is lower than that expected theoretically because adding $\mathrm{OH}^{-}$to an existing solution of $\mathrm{NH}_{4}^{+}$and $\mathrm{HCO}_{3}^{-}$shifts the reaction of Equation 6 to the right. Thus, $\mathrm{NH}_{4}^{+}$dissociation is reduced as compared to theoretical computations because of a lower deficit of exchangeable $\mathrm{H}^{+}$[29]. Interestingly enough, temperature resulting in a lower $\mathrm{CO}_{2}$ concentration and $\mathrm{NH}_{4}^{+}$concentration had less effect at such a $\mathrm{pH}$ range. Nevertheless, the $1750 \mathrm{mg}$ TAN/L solution produced a significantly higher (95\% confidence level) percentage of $\mathrm{NH}_{4}^{+}$dissociation for a $\mathrm{pH}$ range of 7.5 to 9.0 , likely because of its lower concentration requiring less $\mathrm{H}^{+}$. Instead of producing twice the $\mathrm{NH}_{3}$, the $3500 \mathrm{mg}$ TAN/L solution produced only $10 \%$ more $\left(6 \times 10^{-9}\right.$ moles of $\mathrm{NH}_{3}$ as compared to $5 \times 10^{-9}$ moles of $\mathrm{NH}_{3}$ ) as compared to the $1750 \mathrm{mg} / \mathrm{L}$ solution at a pH of 7.5 to 9.0 .

The ratio of theoretical to measured $\mathrm{p} K_{\mathrm{a}}$ as a function of $\mathrm{pH}$ range is illustrated in Figure 1(b) with error bars based on the coefficient of variance. As compared to Figure 1(a), this comparison better illustrates temperature effects for the $3500 \mathrm{mg}$ TAN/L solution below a pH of 6.5, with more dissociation at $25^{\circ} \mathrm{C}$. At a pH above 6.5, the $1750 \mathrm{mg} / \mathrm{L}$ solution produced a significantly lower ratio of theoretical to measure $\mathrm{p} K_{\mathrm{a}}$ as compared to the $3500 \mathrm{mg}$ TAN/L solution (95\% probability). For the $3500 \mathrm{mg}$ TAN/L solution at $15-20$ and $25^{\circ} \mathrm{C}$, and the $1750 \mathrm{mg}$ TAN/L solution at $25^{\circ} \mathrm{C}$, the measured $\mathrm{p} K_{\mathrm{a}}$ was reduced by $9.65,9.69$ and 9.81 respectively, as oppose to that computed theoretically.

In conclusion and at neutral $\mathrm{pH}$ range, simple $\mathrm{NH}_{4} \mathrm{Cl}$ solutions do not dissociate according to the theoretical $\mathrm{p} K_{\mathrm{a}}$ coefficient associated with pure solutions. Rather and because of the presence of especially dissolved atmospheric $\mathrm{CO}_{2}$, the $\mathrm{NH}_{4} \mathrm{Cl}$ solutions demonstrated a lower dissociation level compared to theoretical values, by a factor of 1.5 to 2.3, for TAN concentrations of 1750 to $3500 \mathrm{mg} / \mathrm{L}$. Nevertheless, at a $\mathrm{pH}$ under 6 and a temperature of $25^{\circ} \mathrm{C}$, such solutions tended to demonstrate a higher dissociation levels as compared to the theoretical values for pure solutions.

\subsection{Ammonium Dissociation with Swine and Cattle Manures}

The swine manure was tested at different temperatures and dilutions: $20^{\circ} \mathrm{C}$ to $25^{\circ} \mathrm{C}$ for a dilution of 0 (1 part manure to 0 part distilled water); 8 to 15 and $20^{\circ} \mathrm{C}$ to $25^{\circ} \mathrm{C}$ for a dilution of 1 ( 1 part manure to 1 part distilled water), and; 8 to 15 and $20^{\circ} \mathrm{C}$ to $25^{\circ} \mathrm{C}$ for a dilution of 4 (1 part manure to 4 parts distilled water). The four dilutions produced 3800, 1910 and $765 \mathrm{mg}$ TAN/L, where the first two dilutions had a TAN equivalent to that of the two $\mathrm{NH}_{4} \mathrm{Cl}$ solutions.

Because manures contain a much wider range of compounds and solids, their $\mathrm{NH}_{4}^{+}$dissociation as a function of $\mathrm{pH}$ should be more complex and variable than that of the $\mathrm{NH}_{4} \mathrm{Cl}$ solutions. Manures contain: solids affecting viscosity and therefore the rate of exchange of $\mathrm{CO}_{2}$ with the atmosphere; organics generating dissolved gases such as $\mathrm{CO}_{2}, \mathrm{H}_{2} \mathrm{~S}$ and $\mathrm{CH}_{4}$ as a result of microbial degradation, and; soluble compounds including organic acids and $\mathrm{H}_{3} \mathrm{PO}_{4}[20,21]$ with a lower $\mathrm{p} K_{\mathrm{a}}$ than that of $\mathrm{NH}_{4}^{+}$. For example, acetic acid has a $\mathrm{p} K_{\mathrm{a}}$ of 4.75 compare to that of $\mathrm{NH}_{4}^{+}$at 9.25.

In Figure 2(a), the theoretical to measured $\left[\mathrm{NH}_{3}\right]$ is illustrated as a function of $\mathrm{pH}$. For all three dilutions, the trend is similar to that of the $\mathrm{NH}_{4} \mathrm{Cl}$ solutions. Nevertheless, some differences are observed. Below a $\mathrm{pH}$ of 6.0 and for the dilutions of 1 and 4 , the ratio of theoretical to measured $\left[\mathrm{NH}_{3}\right]$ is lower than that of the $\mathrm{NH}_{4} \mathrm{Cl}$ solutions, likely because of the additional $\mathrm{CO}_{2}$ produced by the microbial activity also know to increase with manure dilution. Still as compared to the $\mathrm{NH}_{4} \mathrm{Cl}$ solutions and for a pH of 6 to 8 , the ratio of theoretical to measured $\left[\mathrm{NH}_{3}\right]$ reaches a higher peak of 2.4 to 3.5, with higher values associated to the higher TAN swine manures with lower dilution rate.

At a $\mathrm{pH}$ under 6.0, higher $\mathrm{CO}_{2}$ levels generated from microbial activity and lower TAN concentrations for the diluted manures push the ratio of theoretical to measured $\left[\mathrm{NH}_{3}\right]$ towards lower numbers below 1.0. This ratio for the less diluted manure at $3800 \mathrm{mg}$ TAN/L remained generally above 1.0 , similarly to the $3500 \mathrm{mg}$ TAN/L solution of $\mathrm{NH}_{4} \mathrm{Cl}$. For a pH of 6 to 9 , the swine manure diluted 4 times tended to present a theoretical to measured $\left[\mathrm{NH}_{3}\right]$ ratio of more or less 1.0. This can simply result from its dilution producing a lower TAN concentrations requiring less $\mathrm{H}^{+}$for the dissociation process.

Still for the swine manure, the ratio of theoretical to measured $\mathrm{p} K_{\mathrm{a}}$ as a function of $\mathrm{pH}$ is illustrated in Figure 2(b) with a trend similar to that of the $\left[\mathrm{NH}_{3}\right]$ ratio. On the average and for a pH between 6.5 and 9, the measured $\mathrm{p} K_{\mathrm{a}}$ for the swine manure diluted to a level of 0,1 and 4 produced a $\mathrm{p} K_{\mathrm{a}}$ equal to $0.96,0.975$ and 0.995 times that computed theoretically. For all $\mathrm{pH}$ tested, the ratio of theoretical to measured $\mathrm{p} K_{\mathrm{a}}$ was inversely proportional to the swine manure TAN. Because of the result variability caused by the presence of other compounds, the difference was significant between the 0:1 and 4:1 dilutions 


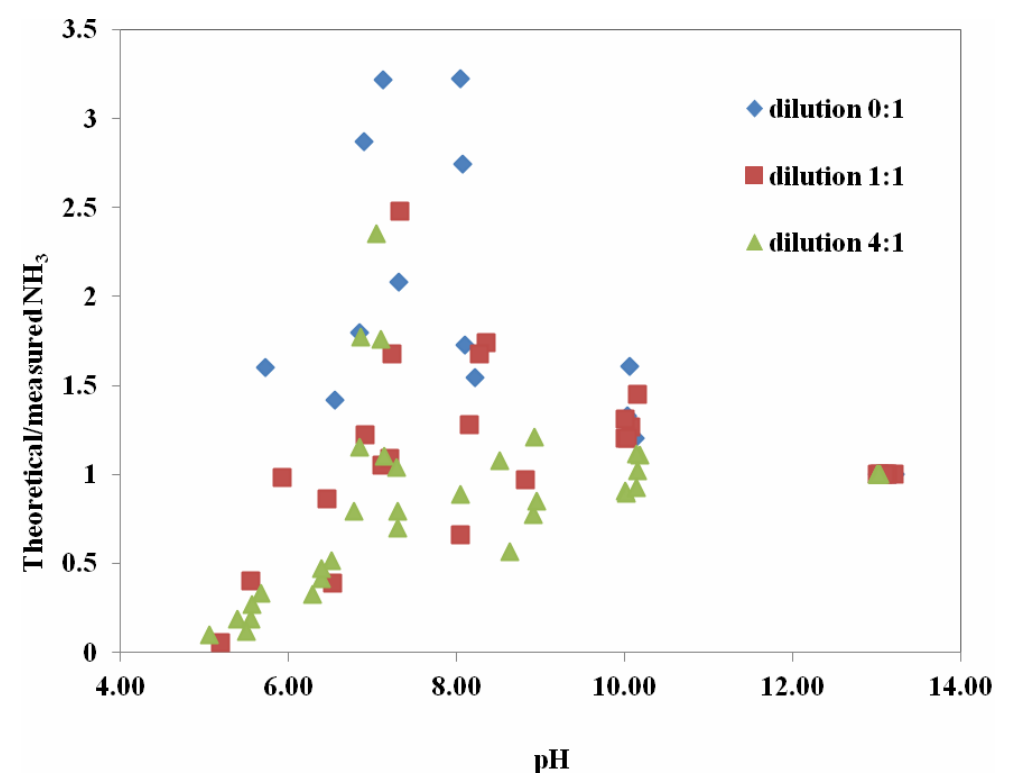

(a)

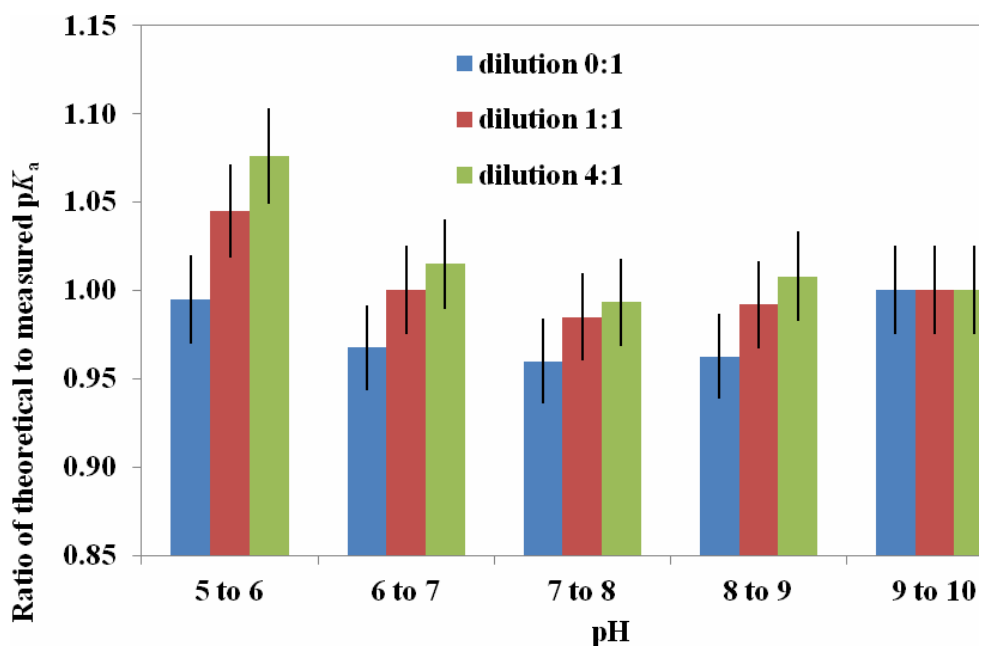

(b)

Figure 2. (a) For swine manure, ratio of theoretical to measured $\mathrm{NH}_{3}$ concentrations as a function of solution pH for temperatures of $20^{\circ} \mathrm{C}$ to $25^{\circ} \mathrm{C}$ at a dilution of 0 (1 part manure to 0 part distilled water); $8^{\circ} \mathrm{C}$ to $15^{\circ} \mathrm{C}$ and $20^{\circ} \mathrm{C}$ to $25^{\circ} \mathrm{C}$ at a dilution of 1 (1 part manure to 1 part distilled water), and; $8^{\circ} \mathrm{C}$ to $15^{\circ} \mathrm{C}$ and $20^{\circ} \mathrm{C}$ to $25^{\circ} \mathrm{C}$ at a dilution of $4(1$ part manure to 4 parts distilled water). (b) Average ratio of theoretical to measured $\mathrm{p} K_{\mathrm{a}}$ versus a rqnge of $\mathrm{pH}$ for swine manure at: $20^{\circ} \mathrm{C}$ to $25^{\circ} \mathrm{C}$ and a dilution of 0 (1 part manure to 0 part distilled water); $8^{\circ} \mathrm{C}$ to $15^{\circ} \mathrm{C}$ and $20^{\circ} \mathrm{C}$ to $25^{\circ} \mathrm{C}$ and a dilution of 1 (1 part manure to 1 part distilled water), and; $8^{\circ} \mathrm{C}$ to $15^{\circ} \mathrm{C}$ and $20^{\circ} \mathrm{C}$ to $25^{\circ} \mathrm{C}$ and a dilution of 4 (1 part manure to 4 parts distilled water). The error bar is based on the coefficient of variance.

(95\% confidence level) only for a pH of 5.0 to 6.0.

The ratio of theoretical to measured $\left[\mathrm{NH}_{3}\right]$ of the dairy manure diluted 4 times is illustrated in Figure 3(a) at a TAN of $400 \mathrm{mg} / \mathrm{L}$. This ratio follows the trends observed with the swine manure and the $\mathrm{NH}_{4} \mathrm{Cl}$ solutions. Nevertheless, the $8^{\circ} \mathrm{C}$ to $15^{\circ} \mathrm{C}$ tests provided a linear relationship with $\mathrm{pH}$, on the average and despite the result variation, whereas the $25^{\circ} \mathrm{C}$ test demonstrated a ratio decreasing from 2.6 to 1.2 , for a $\mathrm{pH}$ of 7 to 9 . This may result from a more active microbial population at $25^{\circ} \mathrm{C}$ since the samples were left on the bench top for $24 \mathrm{~h}$ before testing. Cattle manure has higher fiber content than that of swine manure, offering a lower and more variable microbial digestibility especially at low temperatures.

For the diluted cattle manure, the ratio of theoretical to measured $\mathrm{p} K_{\mathrm{a}}$ as a function of $\mathrm{pH}$ is illustrated in Figure 3(b). This figure demonstrates the temperature effect on the $\mathrm{p} K_{\mathrm{a}}$ ratio, especially for a $\mathrm{pH}$ of 7 to 8 . On the average and for a $\mathrm{pH}$ between 6.5 and 9 , the measured $\mathrm{p} K_{\mathrm{a}}$ for the dairy cattle manure was equal to 0.975 and 0.98 


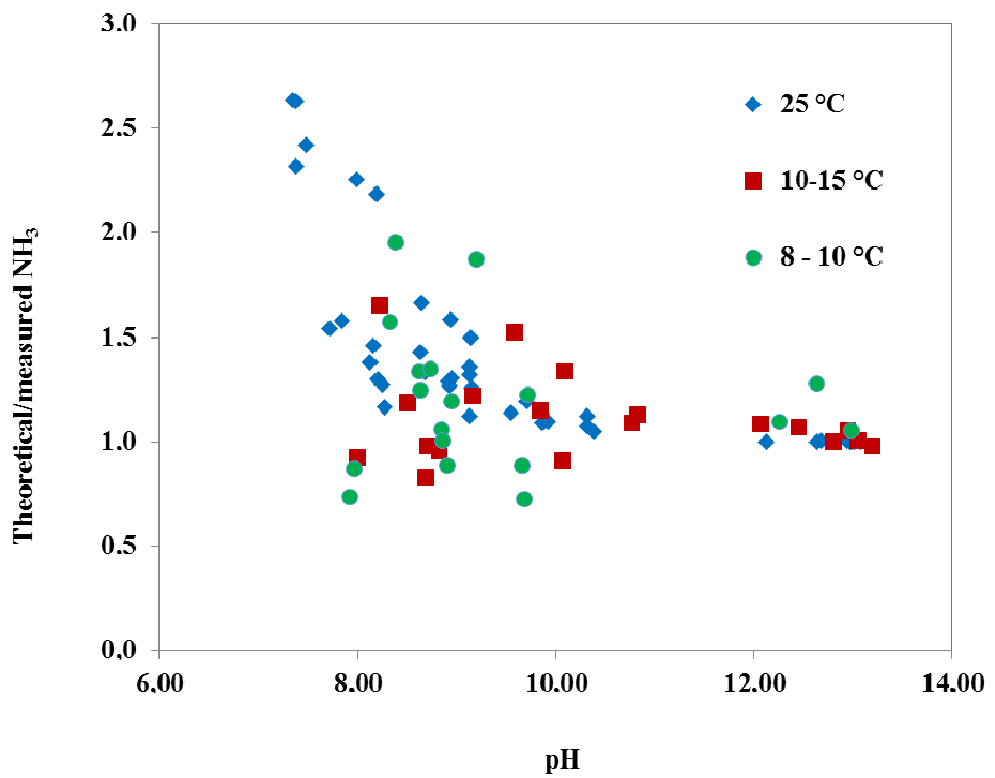

(a)

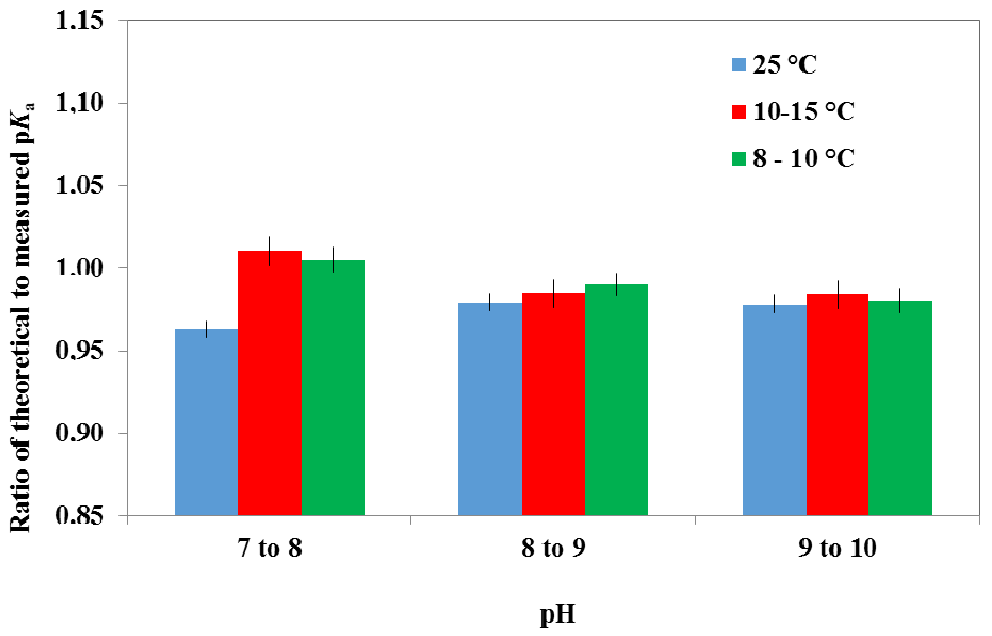

(b)

Figure 3. (a) Ratio of theoretical to measured $\mathrm{NH}_{3}$ concentrations as a function of solution pH for temperatures of $8{ }^{\circ} \mathrm{C}-10^{\circ} \mathrm{C}$, $10^{\circ} \mathrm{C}-15^{\circ} \mathrm{C}$ and $25^{\circ} \mathrm{C}$, for dairy manure at a dilution of $1: 4$ (1 part manure and 4 parts distilled water). (b) Average ratio of the theoretical to measured $\mathrm{p} K_{\mathrm{a}}$ as a function of a $\mathrm{pH}$ range for cattle manure at temperatures of $8^{\circ} \mathrm{C}-10^{\circ} \mathrm{C}, 10^{\circ} \mathrm{C}-15^{\circ} \mathrm{C}$ and $25^{\circ} \mathrm{C}$, and a dilution of 1:4 (1 part manure and 4 parts distilled water). The error bar is based on the coefficient of variance.

times that computed theoretically.

\section{Conclusions}

The objective of the present research was to measure the level of $\mathrm{NH}_{4}^{+}$dissociation at temperature of $10^{\circ} \mathrm{C}$ to $25^{\circ} \mathrm{C}$, for two $\mathrm{NH}_{4} \mathrm{Cl}$ solutions, and for swine and dairy cattle manure at different dilutions with distilled water. Ammonia concentrations ([ $\left.\left[\mathrm{NH}_{3}\right]\right)$ were measured using an $\mathrm{NH}_{3}$ selective electrode consisting of a hydrogen and silver-silver chloride electrode couple connected to a $\mathrm{pH}$ meter. The theoretical and measured $\left[\mathrm{NH}_{3}\right]$ and dissociation coefficient, $\mathrm{p} K_{\mathrm{a}}$, were compared as a function of $\mathrm{pH}$ and temperature, respectively.

The results obtained with the two $\mathrm{NH}_{4} \mathrm{Cl}$ solutions indicated that $\mathrm{NH}_{4}^{+}$dissociation is highly influenced by dissolved compounds, especially atmospheric $\mathrm{CO}_{2}$ with a lower $\mathrm{p} K_{\mathrm{a}}$ coefficient and therefore a greater affinity for $\mathrm{H}^{+}$. Dissolved $\mathrm{CO}_{2}$ had the effect of increasing $\mathrm{NH}_{4}^{+}$dissociation at a $\mathrm{pH}$ under 6 , but decreasing its dissociation at a $\mathrm{pH}$ of 6 to 10 , resulting in a measured $\mathrm{p} K_{\mathrm{a}}$ higher than that computed theoretically. Lowering the TAN concentration of the solution produced a measured $\left[\mathrm{NH}_{3}\right]$ approaching that computed theoretically because of a lower $\mathrm{H}^{+}$demand.

For the swine and dairy cattle manures, the ratio of 
theoretical to measured $\left[\mathrm{NH}_{3}\right]$ was also influenced by the TAN concentration or the level of dilution with distilled water. The more diluted manure showed a dissociation activity approaching that computed theoretically. Nevertheless, the undiluted swine manure produced a ratio of theoretical to measured $\left[\mathrm{NH}_{3}\right]$ of 3.3 at a neutral $\mathrm{pH}$. For the two solutions and manures tested, temperature within a range of $10^{\circ} \mathrm{C}$ to $25^{\circ} \mathrm{C}$, had little if any effect on $\mathrm{NH}_{4}^{+}$ dissociation for a normal pH range of 6.5 to 9 .

The present research therefore indicates that manures and $\mathrm{NH}_{4}^{+}$solutions, exposed to atmosphere and at a neutral $\mathrm{pH}$, show less $\mathrm{NH}_{4}^{+}$dissociation activity than that expected theoretically, by a factor ranging from 1.5 to 3.3. This factor is influenced by the TAN concentration of the manure or solution, with lower TAN levels producing values closer to those computed theoretically. With previous research projects reporting 5 times less $\mathrm{NH}_{3}$ volatilization as compared to theoretical computations, the present indicates that this phenomena results from a dissociation activity generally 2.5 times lower, and thus, a gas diffusion process 2.0 times slower.

\section{Acknowledgements}

This project was funded by the Natural Science and Engineering Research Council of Canada.

\section{REFERENCES}

[1] S. C. Doney, N. Mahowald, I. Lima, R. A. Feely, F. T. Maclenzie, J.-F. Lamarque and P. J. Rasch, "Impact of Anthropogenic Atmospheric Nitrogen and Sulphur Deposition on Ocean Acidification and the Inorganic Carbon System," Proceedings of the National Academy of Sciences, Vol. 104, No. 37, 2007, pp. 14580-14585. doi:10.1073/pnas.0702218104

[2] USDA, “National Program on Air Quality: Component II: Ammonia and Ammonium Emissions".

www.ars.usda.gov/research/programs/programs.htm?np_c ode $=203 \&$ docid $=320$ \&page $=2$

[3] S. G. Sommer and N. J. Hutchings, “Ammonia Emission from Field Applied Manure and Its Reduction-Invited Paper," European Journal of Agronomy, Vol. 15, No. 1, 2001, pp. 1-15. doi:10.1016/S1161-0301(01)00112-5

[4] P. Sørensen and J. Eriksen, "Effect of Slurry Acidification with Sulfuric Acid Combined with Aeration on the Turnover and Plant Availability of Nitrogen,” Agriculture, Ecosystems and Environment, Vol. 131, No. 3-4, 2009, pp. 240-246. doi:10.1016/j.agee.2009.01.024

[5] A. H. W. Beusen, A. F. Bouwman, P. S. C. Heuberger, G. van Drecht and G. K. W. van Der Hoek, "Bottom up Uncertainty Estimate of Global Ammonia Emissions from Global Agricultural Systems,” Atmospheric Environment, Vol. 42, No. 24, 2008, pp. 6067-6077. doi:10.1016/j.atmosenv.2008.03.044

[6] M. Sutton, S. Reis and S. Baker, "Atmospheric Ammonia,” Springer Publishers, Cambridge, 2009. doi:10.1007/978-1-4020-9121-6

[7] J. Seedorf and J. Hartung, "Survey of Ammonia Concentrations in Livestock Buildings,” The Journal of Agricultural Science, Vol. 133, No. 4, 2009, pp. 433-437. doi:10.1017/S0021859699007170

[8] B. Ulrich, "Interaction of Forest Canopies with Atmospheric Constituents: $\mathrm{SO}_{2}$, Alkali and Earth Alkali Cations and Chloride," In: B. Ulrich and J. Pankrath, Eds., Effect of Accumulation of air Pollutants in Forest Ecosystems, D. Reidel Publishers, Dordrecht, 1991, pp. 330-345.

[9] H. Ellenberg, "Floristic Changes Due to Nitrogen Deposition in Central Europe,” Nord Miljorapport, Vol. 15, 1988, pp. 375-383.

[10] B. Aaby, "Monitoring Danish Raised Bogs,” In: A. Grunig, Ed., Mires and Man. Mire Conservation in a Densely Populated Country-The Swiss Experience, Komos Publishers, Birmensdorf Switzerland, 1994, pp. 284-300.

[11] S. C. Doney, N. Mahowald, I. Lima, R. A. Feely, F. T. Maclenzie, J.-F. Lamarque and P. J. Rasch, "Impact of Anthropogenic Atmospheric Nitrogen and Sulfur Deposition on Ocean Acidification and the Inorganic Carbon System," Proceedings of the National Academy of Sciences, Vol. 104 No. 37, 2007, pp. 14580-14585. doi:10.1073/pnas.0702218104

[12] M. A. Sutton, C. E. R. Pitcain and D. Fowler, “The Exchange of Ammonia between the Atmosphere and Plant Communities,” Advances in Ecological Research, Vol. 24, 1993, pp. 301-393. doi:10.1016/S0065-2504(08)60045-8

[13] E. Brouwer, R. Bobbink, F. Meeuwsen and J. G. M. Roelofs, "Recovery from Acidification in Aquatic Mesocosms after Reducing Ammonium and Sulphate Deposition,” Aquatic Botany, Vol. 56, No. 2, 1997, pp. 119-130.

[14] S. Fleischer," $\mathrm{CO}_{2}$ Deficit in Temperature Forest Soils Receiving High Atmospheric N-Deposition," Royal Swedish Academy of Sciences, Vol. 32, No. 1, 2003, pp. 2-5.

[15] L. J. M. Van der Eerden, P. H. B. de Visser and C. J. Van Dijk, "Risk of Damage to Crops in the Direct Neighbourhood of Ammonia Sources," Environmental Pollution, Vol. 102, No. 1, 1998, pp. 49-53. doi:10.1016/S0269-7491(98)80014-6

[16] A. G. Hashimoto and D. C. Ludington, "Ammonia Desorption from Concentrated Chicken Manrue Slurries,” Livestock Waste Management and Pollution Abatement: The Proceedings of the International Symposium on Livestock Wastes, Paper PROC-271. ASABE, St. Joseph, 1971, pp. 117-121.

[17] H. Chaoui, F. Montes, C. A. Rotz and T. L. Richard, "Dissociation and Mass Transfer Coefficients from Ammonia Volatilization Models,” Annual International Meeting. Paper 083802. ASABE, St. Joseph, 2008, pp. 117121.

[18] R. H. Zhang, P. Yang, Z. Pan, T. D. Wolf and J. H. Turnbull, "Treatment of Swine Wastewater with Biological Conversion, Filtration, and Reverse Osmosis: A Laboratory Study," Transactions of the ASAE, Vol. 47, No. 1, 2004, pp. 243-250.

[19] L. Masse, D. Masséand Y. Pellerin, "The Effect of pH on 
the Separation of Manure Nutrients with Reverse Osmosis Membranes,” Journal of Membrane Science, Vol. 325, No. 2, 2008, pp. 914-919. doi:10.1016/j.memsci.2008.09.017

[20] R. Loerh, "Pollution Control for Agriculture," 2nd Edition, Academic Press Inc. (Harcourt Brace Jovanovich Publishers), Orlando, 1984, pp. 166-168.

[21] S. D. Hafner and J. J. Bisogni, "Modeling of Ammonia Speciation in Anaerobic Digesters," Water Research, Vol. 43, No. 17, 2009, pp. 4105-4114. doi:10.1016/j.watres.2009.05.044

[22] R. G. Bates and G. D. Pinching, "Acid Dissociation Constant of Ammonium Ion at 0 to $5^{\circ} \mathrm{C}$ and the Base Strength of Ammonia," Journal of Research National, Bureau Standard, Vol. 42, 1949, p. 419. doi:10.6028/jres.042.037

[23] R. G. Bates and G. D. Pinching, "Dissociation Constant of Aqueous Ammonia at 0 to $5^{\circ} \mathrm{C}$ from E. m. f. Studies of the Ammonium Salt in a Weak Acid," Journal of American Chemical Society, Vol. 72, No. 3, 1950, pp. 13931396. doi:10.1021/ja01159a087

[24] APHA, "Standard Methods for the Analysis of Water and Wastewater," American Public Health Association, Wa- shington DC, 2005.

[25] G. R. Jayaweera and D. A. Mikkelsen, "Ammonia Volatilization from Flood Soil Systems: A Computer Model," Soil Science Society of America Journal, Vol. 54, No. 5, 1990, pp. 1447-1455. doi:10.2136/sssaj1990.03615995005400050039x

[26] G. Olofsson, “Thermodynamic Quantities for the dissociation of Ammonium Ion and for the Ionization of Aqueous Ammonia over a Wide Temperature Range,” Journal of Chemical Thermodynamics, Vol. 7, No. 6, 1975, pp. 507514. doi:10.1016/0021-9614(75)90183-4

[27] R. H. Piedrahita and A. Seland, "Calculation of $\mathrm{pH}$ in Fresh and Seawater Aquaculture Systems,” Aquaculture Engineering, Vol. 14, No. 4, 1995, pp. 331-346. doi:10.1016/0144-8609(94)00012-P

[28] D. Georgacaris, D. M. Sievers and E. L. Iannotti, "Buffer Stability in Manure Digesters,” Agricultural Wastes, Vol. 4, No. 6, 1982, pp. 427-441. doi:10.1016/0141-4607(82)90038-5

[29] M. L. Davis and S. J. Masten, "Principles of Environmental Engineering and Science,” McGraw Hill Publishers, New York, 2004, p. 69. 